\title{
Niveulone, a Heterocyclic Spiro Terpenoid from the Ascomycete Dasyscyphus niveus
}

\author{
Veronica Rojas de la Parra, Viktor Mierau, Timm Anke, Olov Sterner
}

Received: September 19, 2005 / Accepted: January 6, 2006

(C) Japan Antibiotics Research Association

\begin{abstract}
The new heterocyclic spiro terpenoid niveulone (1) was isolated from the cultural fluid of the ascomycete Dasyscyphus niveus, and its chemical structure and relative configuration were determined by spectroscopic techniques.
\end{abstract}

Keywords niveulone, heterocyclic spiro terpenoid, Dasyscyphus niveus

Niveulone (1) was isolated as one of several biologically active metabolites of the ascomycete Dasyscyphus niveus, as described in a preceding paper [1]. It is weakly cytotoxic towards human cell lines, and has an interesting as well as challenging structure with an interesting carbon skeleton. The structure was elucidated by spectroscopic techniques. The 1D NMR data recorded in $\mathrm{CDCl}_{3}$ as well as in $\mathrm{C}_{6} \mathrm{D}_{6}$ are presented in Table 1. MS experiments with FAB ionization revealed that the molecular weight of niveulone (1) is 442 , as a molecular ion of $443(\mathrm{M}+\mathrm{H})$ was obtained under normal conditions while $465(\mathrm{M}+\mathrm{Na})$ and 481 $(\mathrm{M}+\mathrm{K})$ appeared when $\mathrm{NaOAc}$ or KOAc was added to the sample. High resolution experiments suggested that the elemental composition is $\mathrm{C}_{27} \mathrm{H}_{38} \mathrm{O}_{5}$, as the correct exact masses were obtained for $\mathrm{M}+\mathrm{H}, \mathrm{M}+\mathrm{Na}$, and $\mathrm{M}+\mathrm{K}$. This composition is in perfect agreement with the NMR data which show the presence of 27 carbons and 36 hydrogens bound to carbons. This gives 19 unsaturations, and although the number of double bonds was difficult to determine based on the 1D NMR data alone it was obvious that the compound contains several rings.
The structure of niveulone (1) (see Fig. 1) was essentially determined from 2D NMR spectroscopy (COSY, HMQC and $\mathrm{HMBC}$ ) while the relative stereostructure was determined based on NOESY data (see Fig. 2 for a summary of the pertinent HMBC and NOESY correlations observed). A critical partial structure to address was the pyranone moiety. $\mathrm{HMBC}$ correlations from $20-\mathrm{H}_{3}$ to two carbons only, C-18 and C-19, and from $21-\mathrm{H}_{3}$ to C-17, C18 and $\mathrm{C}-19$, suggested that the two methyls are vicinal and positioned on a highly polarized C-18/C-19 carbon-carbon double bond substituted with a heteroatom (oxygen) at C19 and adjacent to the unsaturated carbon C-17. HMBC correlations from $15-\mathrm{H}_{2}$ to $\mathrm{C}-16, \mathrm{C}-17$ and $\mathrm{C}-22$ reveal the remaining carbons of the pyranone, that have the expected high field (C-16 and C-18) and low field (C-17, C-19 and $\mathrm{C}$-22) resonances. The distinction between a 2-pyranone (with C-22 as the carbonyl carbon) and a 4-pyranone (with $\mathrm{C}-17$ as the carbonyl carbon) was facilitated by a synthetic study of the pyranoditerpene lygodinolide (2) [2], that produced both variants. Comparing the carbon resonances obtained for the pyranone moiety of niveulone (1) with those reported for the spiro furo-2-pyranone and the spiro furo-4-pyranone derivatives [2] clearly show that $\mathbf{1}$ is a 2 pyranone. C-15 is obviously also attached to C-14, as $15-\mathrm{H}_{2}$ gives $\mathrm{HMBC}$ correlations also to $\mathrm{C}-8, \mathrm{C}-13$ and $\mathrm{C}-14$, while the methyl groups $\mathrm{C}-23$ (attached to $\mathrm{C}-13$ ) and $\mathrm{C}-24$ (attached to $\mathrm{C}-8$ ) both give $\mathrm{HMBC}$ correlations to $\mathrm{C}-14$ without being geminal. In addition, $23-\mathrm{H}_{3}$ gives $\mathrm{HMBC}$ correlations to $\mathrm{C}-12$ and $\mathrm{C}-13$, a carbon-carbon double bond, while $24-\mathrm{H}_{3}$ also correlates with C-7, C-8 and C-9. With three substituents bound by carbon-carbon single bonds $\mathrm{C}-14$ is obviously not unsaturated, although its ${ }^{13} \mathrm{C}$
O. Sterner (Corresponding author), V. Rojas de la Parra: Department of Organic Chemistry, Lund University, P.O.Box 124, S-22100 Lund, Sweden, E-mail: Olov.Sterner@organic.lu.se
V. Mierau, T. Anke: Institute of Biotechnology and Drug Research IBWF, Erwin-Schrödinger-Str. 56, D-67663 Kaiserslautern, Germany 

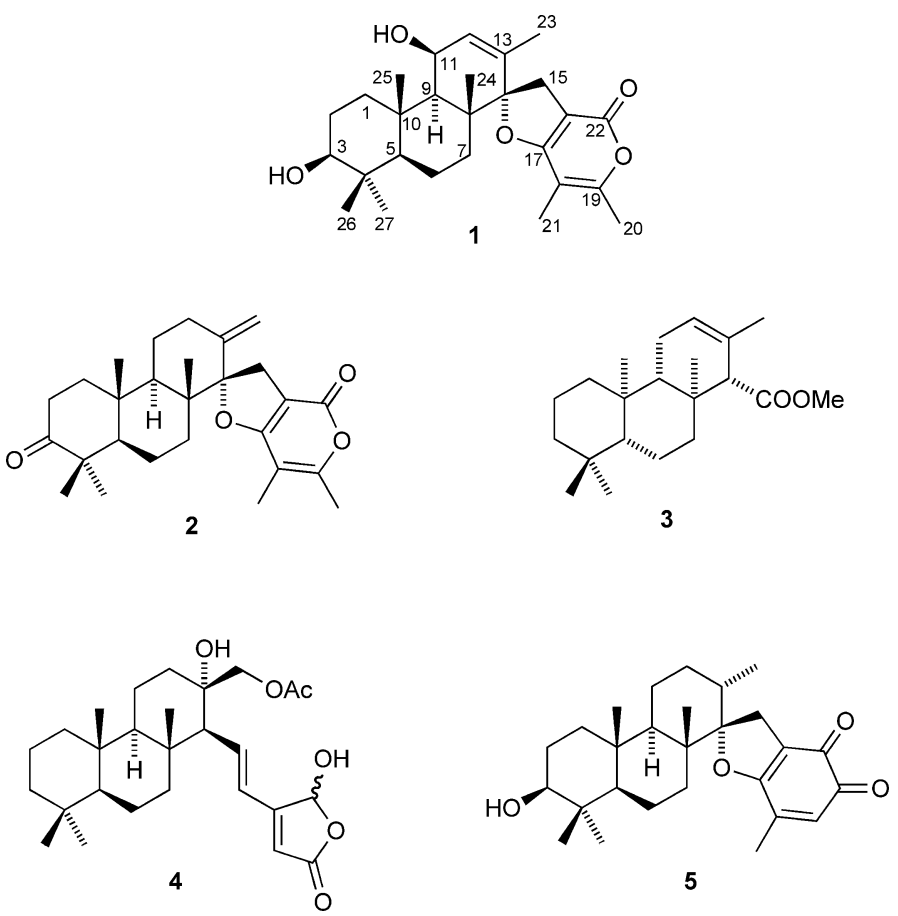

Fig. 1 The structure and relative configuration of the pyranoditerpenes niveulone (1) and lygodinolide (2).

The previously reported products methyl isocopalate (3), spongianolide A (4) and stypoldione (5) are shown with the absolute configuration.
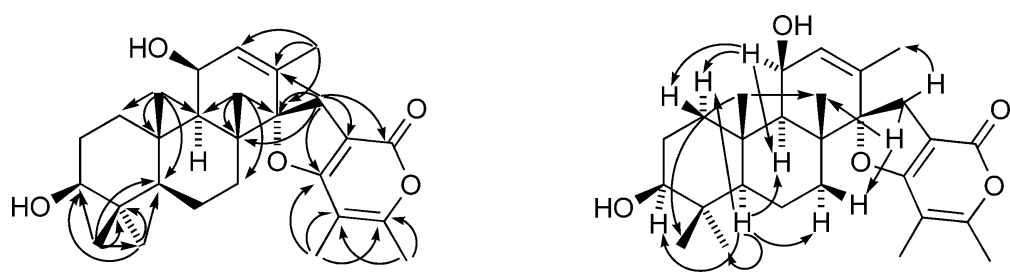

Fig. 2 Pertinent HMBC (left) and NOESY (right) correlations observed with niveulone (1).

NMR shift (99 ppm) is lower than expected if the fourth substituent is an oxygen. The clear COSY as well as $\mathrm{HMBC}$ correlations between $9-\mathrm{H}$ and $11-\mathrm{H}$ as well as $11-\mathrm{H}$ and $12-\mathrm{H}$, and between $12-\mathrm{H}$ and $\mathrm{C}-9$, close the C-ring. HMBC correlations from the remaining methyl protons, from $25-\mathrm{H}_{3}$ to $\mathrm{C}-1, \mathrm{C}-5, \mathrm{C}-9$ and $\mathrm{C}-10$, from $26-\mathrm{H}_{3}$ to $\mathrm{C}-3$, C-4, C-5 and C-27, and from $27-\mathrm{H}_{3}$ to C-3, C-4, C-5 and C26 reveal a spin system that comprises almost all remaining carbons. Cosy correlations between $2-\mathrm{H}_{2}$ and $1-\mathrm{H}_{2}$ as well as $3-\mathrm{H}$, and $\mathrm{HMBC}$ correlations from $1-\mathrm{H}_{2}$ and $3-\mathrm{H}$ to $\mathrm{C}-2$ close the A-ring, while COSY correlations between $6-\mathrm{H}_{2}$ and $5-\mathrm{H}$ as well as $7-\mathrm{H}_{2}$ together with $\mathrm{HMBC}$ correlations from $5-\mathrm{H}$ and $7-\mathrm{H}_{2}$ to $\mathrm{C}-6$ close the B-ring. With all atoms incorporated in the structure and 8 of the 9 unsaturations accounted for, nothing but closing the five-membered ring with the oxygen between $\mathrm{C}-14$ and $\mathrm{C}-17$ is possible.
Niveulone (1) consequently contains a 2,3-dihydrofuro[3,2c]pyran-4-one moiety that is linked to a more traditional terpenoid part in a heterocyclic spiro compound.

The relative configuration of niveulone (1) was determined from NOESY correlations. Correlations between $25-\mathrm{H}_{3}$ and $24-\mathrm{H}_{3}$ as well as $26-\mathrm{H}_{3}$, and between $5-\mathrm{H}$ and $1-\mathrm{H} \alpha(1-\mathrm{Hb}$ in Table 1), 3- $\mathrm{H}, 7-\mathrm{H} \alpha$ (7- $\mathrm{Hb}$ in Table 1), 9- $\mathrm{H}$, and $27-\mathrm{H}_{3}$ show that the connections between rings $\mathrm{A} / \mathrm{B}$ and $\mathrm{B} / \mathrm{C}$ are as usual, trans. NOESY correlations for $11-\mathrm{H}$ were observed to both $1-\mathrm{H} \alpha$ and $1-\mathrm{H} \beta$ as well as to $9-\mathrm{H}$, but not to $25-\mathrm{H}_{3}$. This indicates that $11-\mathrm{H}$ is $\alpha$ as well as equatorial and that $11-\mathrm{OH}$ consequently is $\beta$ and axial. This is consistent with the relatively small coupling constant observed between $9-\mathrm{H}$ and $11-\mathrm{H}, 4.7 \mathrm{~Hz}$ in $\mathrm{CDCl}_{3}$. The relative configuration of the spiro carbon could be determined by the NOESY correlations between 15-Ha and 
Table $1{ }^{1} \mathrm{H}(500 \mathrm{MHz})(\delta$; multiplicity; $J)$ and ${ }^{13} \mathrm{C}(125 \mathrm{MHz})(\delta$; multiplicity $) \mathrm{NMR}$ data for niveulone

\begin{tabular}{|c|c|c|c|c|}
\hline \multirow{2}{*}{ C } & \multicolumn{2}{|l|}{$\mathrm{CDCl}_{3}$} & \multicolumn{2}{|l|}{$\mathrm{C}_{6} \mathrm{D}_{6}$} \\
\hline & ${ }^{1} \mathrm{H}$ & ${ }^{13} \mathrm{C}$ & ${ }^{1} \mathrm{H}$ & ${ }^{13} \mathrm{C}$ \\
\hline $1 a$ & 2.03; ddd; 3.5, 3.9, 12.8 & $38.2 ; \mathrm{t}$ & 1.84; ddd; 3.4, 3.6, 12.9 & $38.8 ; t$ \\
\hline $1 b$ & $1.26 ; m$ & & $1.00 ; m$ & \\
\hline $2 a$ & $1.72 ; m$ & $27.0 ; \mathrm{t}$ & 1.58; m & $28.0 ; t$ \\
\hline $2 b$ & $1.72 ; \mathrm{m}$ & & $1.44 ; \mathrm{m}$ & \\
\hline 3 & $3.26 ; \mathrm{dd} ; 6.5,9.6$ & 78.8; d & $3.03 ; \mathrm{dd} ; 4.5,11.7$ & 79.0; d \\
\hline 4 & - & $38.7 ; \mathrm{s}$ & - & $39.4 ; s$ \\
\hline 5 & $0.72 ; \mathrm{dd}, 4.3,8.7$ & $55.7 ; d$ & $0.71 ; \mathrm{dd} ; 2.9,10.8$ & $56.7 ; d$ \\
\hline 6 & $1.59 ; \mathrm{m}$ & 18.3; t & $1.43 ; \mathrm{m}$ & 19.0; t \\
\hline $7 a$ & 1.50; ddd; 3.1, 3.3, 12.9 & $32.9 ; \mathrm{t}$ & $1.41 ; m$ & $33.5 ; t$ \\
\hline $7 b$ & $1.38 ; m$ & & $1.27 ; \mathrm{m}$ & \\
\hline 8 & - & 40.6; s & - & $41.2 ; \mathrm{s}$ \\
\hline 9 & $1.55 ; \mathrm{d} ; 4.7$ & $51.1 ; d$ & $1.55 ; d ; 4.8$ & $52.0 ; d$ \\
\hline 10 & - & 38.0; s & - & $38.7 ; \mathrm{s}$ \\
\hline 11 & $4.49 ; \mathrm{dd} ; 4.7,4.9$ & $65.3 ; d$ & $4.18 ; t ; 4.8$ & 65.6; d \\
\hline 12 & $5.70 ; d ; 4.9$ & 129.6; d & $5.27 ; d ; 4.8$ & $130.4 ; d$ \\
\hline 13 & - & $133.7 ; \mathrm{s}$ & - & 134.0; s \\
\hline 14 & - & $99.4 ; s$ & - & 99.8; s \\
\hline $15 a$ & $3.04 ; d ; 15.9$ & $29.3 ; t$ & $3.01 ; d ; 15.9$ & $30.6 ; t$ \\
\hline $15 b$ & $2.98 ; d ; 15.9$ & & $2.94 ; d ; 15.9$ & \\
\hline 16 & - & 99.6; s & - & 100.3; s \\
\hline 17 & - & 161.9; s & - & 170.7; s \\
\hline 18 & - & 102.8; s & - & 102.4; s \\
\hline 19 & - & $160.5 ; \mathrm{s}$ & - & 160.7; s \\
\hline 20 & $2.22 ; \mathrm{s}$ & 17.2; q & $1.59 ; \mathrm{s}$ & 17.0; q \\
\hline 21 & $1.92 ; \mathrm{s}$ & 9.7; q & 1.45; s & $9.6 ; \mathrm{q}$ \\
\hline 22 & - & 171.0; s & - & 161.0; s \\
\hline 23 & $1.73 ; \mathrm{s}$ & 18.8; q & $1.52 ; \mathrm{s}$ & 19.0; q \\
\hline 24 & $1.21 ; \mathrm{s}$ & $19.5 ; q$ & $1.02 ; \mathrm{s}$ & $19.9 ; q$ \\
\hline 25 & 1.38; s & $17.7 ; q$ & $1.37 ; \mathrm{s}$ & $18.2 ; \mathrm{q}$ \\
\hline 26 & $0.84 ; \mathrm{s}$ & 15.6; q & $0.83 ; \mathrm{s}$ & $16.2 ; \mathrm{q}$ \\
\hline 27 & $0.98 ; \mathrm{s}$ & $28.4 ; \mathrm{q}$ & $1.01 ; \mathrm{s}$ & $29.2 ; q$ \\
\hline
\end{tabular}

The spectra were recorded in $\mathrm{CDCl}_{3}$ and $\mathrm{C}_{6} \mathrm{D}_{6}$, and the solvent signals $\left(7.26\right.$ and $7.16 \mathrm{ppm}$ for ${ }^{1} \mathrm{H} \mathrm{NMR}$, and 77.0 and $128.4 \mathrm{ppm}$ for ${ }^{13} \mathrm{C}$ NMR) were used as reference. The chemical shifts $(\delta)$ are given in ppm and the coupling constants $\mathrm{J}$ are given in $\mathrm{Hz}$. The multiplicities of the carbon signals were determined indirectly from $\mathrm{HMOC}$ experiments.

$24-\mathrm{H}_{3}$ as well as $7-\mathrm{H} \beta$, which is equatorial. As expected, $15-\mathrm{Hb}$ correlates with $23-\mathrm{H}_{3}$, although this is not informative.

Niveulone (1) is a new compound, but shares the carbon skeleton with the pyranoditerpene lygodinolide (2) reported from the fern Lygodium flexuosum [3]. It shares the basic part with the spongian diterpenes, e.g. the isocopalanes (e.g. methyl isocopalate (3) in Fig. 1) which are marine diterpenoids [4], but has a 2-pyranone moiety attached to $\mathrm{C}-15$. There is some resemblance with the cheilanthanes
[5 7], e.g. spongianolide A (4), and the stypoldione type of terpenoids (e.g. stypoldione (5) [8]), although they have different carbon skeletons.

\section{Materials and Methods}

${ }^{1} \mathrm{H}$ NMR $(500 \mathrm{MHz})$ and ${ }^{13} \mathrm{C}$ NMR $(125 \mathrm{MHz})$ spectra were recorded at room temperature with a Bruker DRX500 spectrometer with an inverse multinuclear $5 \mathrm{~mm}$ probehead 
equipped with a shielded gradient coil. The spectra were recorded in $\mathrm{CDCl}_{3}$ and $\mathrm{C}_{6} \mathrm{D}_{6}$, and the solvent signals (see Table 1 for details) were used as reference. COSY, HMQC and $\mathrm{HMBC}$ experiments were recorded with gradient enhancements using sine shaped gradient pulses. For the 2D heteronuclear correlation spectroscopy the refocusing delays were optimised for ${ }^{1} J_{\mathrm{CH}}=145 \mathrm{~Hz}$ and ${ }^{\mathrm{n}} J_{\mathrm{CH}}=10 \mathrm{~Hz}$. The raw data were transformed and the spectra were evaluated with the standard Bruker XWIN-NMR software (rev. 010101). Mass spectra (HRFAB) were recorded with a Jeol SX102 spectrometer. The UV and the IR spectra were recorded with a Varian Cary 2290 and a Perkin Elmer 298 spectrometer, and the optical rotations were measured with a Perkin-Elmer 141 polarimeter at $22^{\circ} \mathrm{C}$.

Niveulone was obtained as a yellowish oil from fermentations of the ascomycete Dasyscyphus niveus, as described in the preceding paper $[1]$. $[\alpha]_{\mathrm{D}}^{20}-23(c 0.5$, $\left.\mathrm{CHCl}_{3}\right) ; \lambda_{\max }(\varepsilon)$ in $\mathrm{MeOH}: 295 \mathrm{~nm}(8,100) ; v_{\max }$ (liquid film) 3435, 2930, 1700, 1575, 1445, 1275, 1115, 1060, 980, 920, 850 and $750 \mathrm{~cm}^{-1} ; \mathrm{m} / z$ HRMS $\left(\mathrm{FAB}, \mathrm{M}+\mathrm{H}^{+}\right.$) found 443.2791. $\mathrm{C}_{27} \mathrm{H}_{39} \mathrm{O}_{5}$ requires 443.2797. See Table 1 for ${ }^{1} \mathrm{H}$ and ${ }^{13} \mathrm{C}$ NMR data.

\section{References}

1. Mierau V, Rojas de la Parra V, Sterner O, Anke T.
Dasyscyphins $\mathrm{A} \sim \mathrm{C}$ and niveulone, new biologically active compounds from the ascomycete Dasyscyphus niveus. J Antibiot 59: $x x x-x x x$ (2006).

2. Banerjee AK, Achari B. Regiocontrolled synthesis of spiro furopyrone-cyclohexane ring systems: Approach to the pyranoditerpene lygodinolide. Tetrahedron Lett 35: 1209-1210 (1993)

3. Achari B, Chaudhuri C, Saha CR, Pakrashi SC, McPhail DR, McPhail ET. X-ray crystal structure of lygodinolide: a novel spiro furopyran-perhydrophenanthrene derivative from Lygodium flexuosum. J Org Chem 55: 4977-4978 (1990)

4. Imamura PM, Ruveda EA. The C-13 configuration of the bromide-containing diterpene isoaplysin-20. Synthesis of debromoisoaplysin-20 and its C-13 epimer. J Org Chem 45: 510-515 (1980)

5. He H, Kulanthaivel P, Baker BJ. New cytotoxic sesterterpenes from the marine sponge Spongia sp. Tetrahedron Lett 35: 7189-7192 (1994)

6. De Rosa S, Crispino A, De Giulio A, Iodice C, Tommonaro G. Cavernosolide, a new sesterterpene from a Tyrrhenian sponge. J Nat Prod 60: 844-846 (1997)

7. Buchanan MS, Edser A, King G, Whitmore J, Quinn RJ. Cheilanthane sesterterpenes, protein kinase inhibitors, from a marine sponge of the genus Ircinia. J Nat Prod 64: 300-303 (2001)

8. Gerwick WH, Fenical W, Fritsch N, Clardy J. Stypotriol and stypoldione; ichthyotoxins of mixed biogenesis from the marine alga Stypopodium zonale. Tetrahedron Lett 20: 145-148 (1979) 